\title{
ADVANCED METHODS OF TEACHING FOREIGN LANGUAGES IN HIGHER EDUCATION INSTITUTIONS
}

\author{
Roziya Eshquvatova \\ Teacher Of Foreign Language, Samarkand State University, Uzbekistan \\ Nargiza Rustamova \\ Teacher Of Foreign Language, Samarkand State University, Uzbekistan
}

\section{ABSTRACT}

In any society, the education of the young generation is based on a specific goal. This article provides the material necessary to improve the professional and pedagogical potential of professors and teachers working in higher education institutions and is aimed at students of foreign languages. Here are some basic facts about an effects pedal and how to use it. Examples and feedback of modern teaching recommendations, experiences in using person-centered learning technologies and interactive methods are provided.

KEYWORDS: - Non-philological educational institutions, international standards, associative line, communication, guessing the subject, intelligent, updating of knowledge.

\section{INTRODUCTION}

One of the current challenges is to educate the young generation in the spirit of love and devotion to the homeland, national pride, high morality and spirituality, pride in our ancient and rich heritage, national values and universal through the teaching of foreign languages. . Radical reforms of the global education system pose the problem of creating the necessary conditions for students to learn foreign languages perfectly, to express themselves in all fields with the knowledge of a foreign language, to develop their oral and written discourse in one language. foreign. Organizations such as UNESCO, UNICEF, the European Association of
Universities and the European Network for the Quality of Higher Education are involved in the development of students' thinking in a foreign language, their ability to speak fluently, their intellectual development and their evaluation. used. The development of these issues into general trends plays an important role in the formation of modern and foreign language skills in the younger generation and serves to increase the creative abilities of students in relation to the problems of modern education.

The basis for the improvement of the higher educational education system in the reform of the educational system of the Republic is the coordination of study programs in accordance with international standards based on foreign 
CURRENT RESEARCH JOURNAL OF PHILOLOGICAL SCIENCES 2(10): 92 -

97, October 2021

DOI: https://doi.org/10.37547/philological-crjps-02-10-18

ISSN 2767-3758

(C)2021 Master Journals

Crossref do

8 Google

Accepted $26^{\text {th }}$ October, 2021 \& Published $31^{\text {th }}$ October, 2021

experience. In the context of Uzbekistan, it is necessary to radically reform the quality of education on the basis of foreign experience, taking into account our mentality and national traditions. Therefore, in order to form the ability to read the original literature on the specialty, participate in oral communication in a foreign language in the production process of future staff and find the necessary information for scientific purposes in the system of higher education of the republic courses are organized.

\section{Main ParT}

Every citizen of the Independent Republic of Uzbekistan should be able to read original literature in a foreign language, understand the text and use it in his profession. In addition, he must be able to communicate freely in a foreign language with his interlocutor on a given subject. After all, learning foreign languages is a requirement of today's globalized world.

Thanks to independence, special attention is paid to the teaching of foreign languages in our country. Thousands of foreign language teachers have been trained, all conditions have been created for the training of personnel in our country and abroad, multimedia manuals in English, German and French, electronic resources for learning the language The organization of the language rooms is clear proof of this. of that. The main objective is to create the conditions for young people to use the achievements of world civilization and information resources around the world, to develop international cooperation and dialogue, based on the education of the young generation in foreign languages and improving the training of specialists. speak these languages fluently. The famous German scientist as von Goethe said, "He who does not know a foreign language does not know his mother tongue." For this reason, it is very important not only for foreign language specialists, but also for all future professionals studying at non-linguistic universities to learn foreign languages and to be able to communicate freely. There is a saying among our people: "He who knows the language, he knows all things". Indeed, a person who knows a foreign language will have many opportunities and advantages. One of the main requirements of staff today is a good command of foreign languages.

In the process of training specialists in all fields, it is important to give priority to the educational system, including the introduction of new technologies and mechanisms for teaching foreign languages. After all, communication, spiritual and other communication between nations is expressed through language.

Research on the teaching of foreign languages to students of non-linguistic higher education institutions around the world is being carried out in the following priority areas: Improving the teaching arrangements for teaching foreign languages to students in accordance with the requirements of the European CEFR; teaching contents, educational technologies, reinforcement of the objectivity of control, organization of autonomous learning in the classroom and outside the classroom.

Foreign language teaching in higher education institutions includes 1) practice or communication, 2) general education, 3) education, 4) use of acquired skills and abilities for other purposes, that is, development objectives. General, educational, and developmental goals occur in pursuit of a communication goal. Let's take a closer look at these 4 goals:

1. Communicative Objective (Practice): Through this objective, students develop material skills in English. Students should be able to use lexical and grammatical pronunciation material 
CURRENT RESEARCH JOURNAL OF PHILOLOGICAL SCIENCES 2(10): 92 -

97, October 2021

DOI: https://doi.org/10.37547/philological-crjps-02-10-18

ISSN 2767-3758

(C)2021 Master Journals

Crossref do

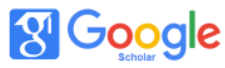

Accepted $26^{\text {th }}$ October, 2021 \& Published $31^{\text {th }}$ October, 2021

independently in speech. English, reading and writing skills will be developed.

2. General Learning Objective: Through this objective, students will be able to develop their thinking, learn and impart information in English, acquire a deeper understanding of English, acquire new knowledge about English and the history, literature and culture of the inhabitants of the country where the language is studied. It is understood that students broaden their view of the world at the expense of acquiring ideas and information about. Students will be able to understand, develop their thinking and broaden their horizons to the detriment of a foreign language or English.

3. Educational objective: This objective is to provide interethnic, moral and aesthetic education in a foreign language - English course, as well as to develop an attitude to work. Of course, this is done by analyzing the subject of English speech, the content of foreign language texts through foreign language documents.

4. Developmental Goal: This goal sets the direction for the student to learn, teach, get to know students personally. It develops the skills necessary to analyze, summarize, draw independent conclusions, listen, speak and act on linguistic facts. It teaches imagination, creating a speaking situation, logical connection in speaking, independent thinking, understanding the meaning of words, independent work with dictionaries, textbooks and electives., develops independent preparation for extracurricular activities, their conduct. The above four objectives are always complementary and interdependent. These four goals are to be achieved through foreign language materials and speaking activities which are taught and repeated in each lesson.

Material METhOD
Active teaching methods not only help motivate students to think actively and concretely about the learning process, but also help to form positive motivation for teaching, reveal and develop creative abilities, master material learning with great efficiency.

Both teacher and student should be active during the lesson. We will focus on some of the advanced methods we use in our courses, pointing out that almost all techniques are mobile and can be used not only in foreign language courses, but also in other academic disciplines.

"Carousel" ("Merry Go Round") This technique allows the use of imaginative thinking, memory. The first student takes a card from the teacher and names the associations with that word. The card is passed along the chain until it is returned to the teacher. Each student has the opportunity to express their ideas quickly.

The questionnaire ("Question Time") is used at different stages of the lesson. It will be easier for the student to respond to his classmate than to the teacher, and the rigidity and fear of error will disappear. The technique is effective for working with "weak" students, allowing them to reinforce the material being studied and identify the shortcomings of each student.

"Surprise" is a method of improving mental activity and arousing interest in a lesson topic. Forms the ability to analyze, separate and shape conflicts. The teacher finds a point of view that even well-known facts remain a mystery. Puzzle Time There are many differences in this methodology which are applied successfully at different stages of the lesson. For example: FIND WORDS between a set of letters on a specific topic; The words ADD A WORD are given, but the letters are omitted; Solve CROSSWORD by answering the questions; Find the word in the puzzles, put the picture together - read the word 
CURRENT RESEARCH JOURNAL OF PHILOLOGICAL SCIENCES 2(10): 92 -

97, October 2021

DOI: https://doi.org/10.37547/philological-crjps-02-10-18

ISSN 2767-3758

(C2021 Master Journals

Crossref do

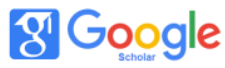

Accepted $26^{\text {th }}$ October, 2021 \& Published $31^{\text {th }}$ October, 2021

on the back.

Tongue Twisting Devices This technique is used to practice correct pronunciation. I always wanted children to learn not only to pronounce a particular sound correctly, but to make it fun.

You can use picture cards for a specific sound and create the same rhyme. At first, the teacher says the rhyme very slowly to familiarize himself with the pronunciation of the sound. Students then rehearse after the teacher in small semantic groups and clap when they hear a given rhyming sound. Explain the meaning of words that the students do not know. The teacher then says the rhyme aloud again and the children repeat. And so 3-4 times.

Example: The one who laughs last does not laugh the best. - The one who laughs for the last time laughs.

Motivational methods for learning activities. The problematic situation (question) helps to develop motivation, interest in the topic, communication, information learning, and pedagogical and organizational skills. The teacher creates a problematic situation, guides the students to solve it, organizes the search for a solution. Thus, the child becomes his own learning position and as a result new knowledge is formed in him, he learns new ways of acting.

Music / video section The teacher prepares a piece of music, an audio recording or a video in advance. After listening to part of the recording or watching the film, the teacher guides students through the discussion to formulate specific goals, objectives or topics for the lesson.

Communication. A special form of communication. It is the interaction between people in a learning environment that takes the form of speaking. There is an exchange of information between the partners and the relationship between them is regulated. The specificity of educational dialogue is determined by the objectives of its participants, the conditions of their interaction.

Such dialogue can easily be directed to the main topic of the lesson. For example, the subject "Your day" can be started by the teacher at the door of the classroom with the teacher's questions: Hello! How do you feel today? At what time did you get up this morning? Did you have breakfast this morning? Did you do your homework today? What do you plan to do after class?

The "guess the subject" method. Students will receive pieces from several puzzles. Find lost parts of friends, form groups and collect puzzles. Students are then asked to guess the topic of the lesson based on the photo taken.

The method of updating knowledge. "Intellectual warm-up" ("magic ball" or "snowball") At this point, students "remember" past material. The principle of "intellectual warm-up" can be used throughout the lesson to develop speaking skills. As a rule, the lexical bases for these exercises are located on the board, especially in the early stages. The growth of the "snowball" can continue in two directions: with increasing vocabulary and / or increasing grammatical complexity. (EXAMPLE: I like reading books । u003e I like reading e-books. \U003e I like reading e-books because they are easy to use.)

Working with signal cards This is a presentation of the material passed in the form of cards. This style helps to create substance, to restore the attention of the students.

Associative row method. For a specific concept of a topic or lesson, you should write word associations in the column. The solution is as follows: if the series is relatively precise and sufficient, give an assignment to create a description using written words; then listen, 
CURRENT RESEARCH JOURNAL OF PHILOLOGICAL SCIENCES 2(10): 92-

97, October 2021

DOI: https://doi.org/10.37547/philological-crjps-02-10-18

ISSN 2767-3758

C)2021 Master Journals

Crossref do

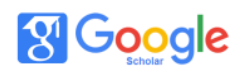

Accepted26 $6^{\text {th }}$ October, 2021 \& Published 31 $1^{\text {th }}$ October, 2021

compare with the dictionary version, you can add new words to the associative line.

\section{Conclusion}

In short, it is very important to teach a foreign language in higher education establishments not specialized in languages, because foreign languages play an important role in preparing students for full development.

Another way to meet the demands of the modern world is to reduce the amount of redundant material for students and to simplify the learning process. These are taken into account in the new foreign language program. The teacher approaches this in terms of the students' overall practical mastery of the subject. For this reason, the work of the students focuses on the development of productive (speaking, writing) and receptive (listening, reading) language, thus increasing the potential of the students. The basis of a good education is the effective generalization and improvement of the teaching process. More recently, optimization has been widely used. Optimization is the search and application of an easy and practical method, method, system, principle, tool and exercise, adapted to the situation, to the conditions , university students and their chosen field of study. Optimization is specific to different types of higher education institutions, as class times vary and students' native language characteristics vary. Nowadays, communication skills, information skills in a foreign language (speaking, not writing) and information acquisition (reading, listening and understanding) to further develop skills and knowledge. abilities, as well as education and education require to wear.

\section{ReFERENCES}

1. A Handbook for Teaching and Learning in
Higher Education EnhancingAcademic Practice 2008, $544 \mathrm{p}$

2. Bent B.Andresen and Katja van den Brink. Multimedia in Education.UNESCO Institute for Information Technologis in Education. 2013.ISBN 978-5-7777-0556-3.

3. D. Tojiboeva, A. Yuldashev. Methods of teaching special subjects. Textbook. $\mathrm{T}$.: "Communicator". 2009. 568 pages.

4. Getting Started: Idea Book on Pedagogy for New Faculty. Faculty Teaching Excellence Program UNIVERSITY OF COLORADO BOULDER Office of Academic Affairs 2008 $82 \mathrm{p}$

5. Khodjaboev A. Khusanov L. Methodology of vocational education. $\mathrm{T}$.: Science and Technology, 2007

6. Mavlyanov A et al. Technology of teaching lessons based on the principles of pedagogical technology "VORIS-Publishing House" - T .: 2010. 112 p.

7. Miled, M. (2003). Quelles spécificités didactiques dans un contexte de français langue seconde ? In J.-L. Dumortier, J.-M. Defays, B. Delcominette, V. Louis (Eds.), L'enseignement $d u$ français aux non francophones. Le poids des situations et des politiques linguistiques (pp. 197-207). Cortil-Wodon : Editions modulaires européennes.

8. Nisubire, P. (2003). Problématique sociolinguistique et didactique du français langue seconde en Afrique. In J.-L. Dumortier, J.-M. Defays, B. Delcominette, V. Louis (Eds.), L'enseignement du français aux non francophones. Le poids des situations et des politiques linguistiques (pp. 209-232). Cortil-Wodon : Editions modulaires européennes. 
CURRENT RESEARCH JOURNAL OF PHILOLOGICAL SCIENCES 2(10): 92-

97, October 2021

DOI: https://doi.org/10.37547/philological-crjps-02-10-18

ISSN 2767-3758

(C)2021 Master Journals

crossref do) 80 Google

Accepted $26^{\text {th }}$ October, 2021 \& Published $31^{\text {th }}$ October, 2021

9. Perregaux, C. (2001). L'intégration sociale et scolaire, aussi une histoire de langue(s). In Chr. Perregaux, T. Ogay, Y. Leanza, P. Dasen (Eds.), Intégrations et migrations. Regards pluridisciplinaires (pp. 317-335). Paris : L'Harmattan.

10. Py, B. (2004). Pour une approche linguistique des représentations sociales. Langages, 154, 6-19.

DOI : 10.3917/lang.154.0006

11. Rispail, M. (2006). Le français en situation de plurilinguisme : un défi pour l'avenir de notre discipline ? Pour une sociodidactique des langues et des contacts de langues. In S. Plane \& M. Rispail (Eds.), La lettre de l'AIRDF, L'enseignement du français dans les différents contextes linguistiques et sociolinguistiques, 38, 512.

1. DOI : $10.3406 /$ airdf.2006.1687

12. Simard, C. (1997). Eléments de didactique $\mathrm{du}$ français langue première. ParisBruxelles : De Boeck et Larcier.

13. Sharples, M., McAndrew, P., Weller, M., Ferguson, R., FitzGerald, E., Hirst, T., Mor,Y., Gaved, M. and Whitelock, D. (2012). Innovating Pedagogy 2012: Open University Innovation Report 1. Milton Keynes: The Open University. 61p

14. Ismatullayeva, N. R. (2021). On the Introduction of E-Learning Portfolio in the Educational Process. Current Research Journal of Pedagogics (2767-3278), 2(09), 35-37. 